\title{
Response of Organic with Mineral Fertilizer Application on the growth and Development of Olive (Olea europaea) Saplings
}

\author{
Muhammad Iqbal Jakhro" ${ }^{*}$, Nadeem Sadiq ${ }^{1}$, Javed Ahmed Abro ${ }^{1}$, Amanullah ${ }^{1}$, Fateh Muhammad ${ }^{2}$, Maq- \\ bool Ahmed ${ }^{3}$, Syed Ishtiaq Ahmed Shah ${ }^{3}$ and Qasid Hussain ${ }^{4}$
}

${ }^{1}$ PARC-Balochistan Agricultural research and Development Centre (BARDC) Quetta, Balochistan, Pakistan; ${ }^{2}$ PARCSocial Sciences Research Institute (SSRI) BARDC Quetta, Balochistan, Pakistan; ${ }^{3}$ Director General Agriculture Extension, Quetta, Balochistan, Pakistan; ${ }^{4}$ PARC-Agriculture Research Institute (ARI), Jaffarabad, Balochistan, Pakistan.

Abstract | This study was conducted at the BARDC Olive field, Quetta during 2019-20 aimed to assess the effect of organic and mineral application of fertilizers on the growth and development of Olive (Olea europaea) saplings as well as to determine the soil physiochemical properties. One-year old Olive plants were applied with organic and inorganic mineral fertilizer application for six months. The results showed that in comparison to control, plants fertilized with T2 (N 50g/plant), T3 (P 25g/plant), T4 (K 25g/plant), T5 (NPK 50:25:25/plant), T6 (Biochar 2:2) and T7 (FYM 2:2) had significant results. The studied parameters which was height of plant, leaves per plant, branches per plants and girth of stem. As regards to soil analysis for nutrients concentration, it is concluded from this study that the observed from various of parameters which is growth and developments of olive saplings and soil nutrient status improved through mineral fertilizer when applied in soil during the two periods (three months), besides treatment 5 (NPK 50:25:25) was the superior in this concern.

Received | February 22, 2021; Accepted | October 14, 2021; Published | January 19, 2022

*Correspondence | Muhammad Iqbal Jakhro, PARC-Balochistan Agricultural research and Development Centre (BARDC) Quetta, Balochistan, Pakistan; Email: iqbal.jakhro@gmail.com

Citation | Jakhro, M.I., N. Sadiq, J.A. Abro, Amanullah, F. Muhammad, M. Ahmed, S.I.A. Shah and Q. Hussain. 2022. Response of organic with mineral fertilizer application on the growth and development of olive (Olea europaea) saplings. Pakistan Journal of Agricultural Research, 35(1): $15-20$.

DOI | https://dx.doi.org/10.17582/journal.pjar/2022/35.1.15.20

Keywords | Growth, Yield, Mineral fertilizer, Olive

\section{Introduction}

$\mathrm{O}_{2}$ live cultivation began more than 6,000 years ago and is still flourishing today not just in the lands from which they came, however now in many parts of the world. The olive is local to the Mediterranean vicinity, tropical and vital Asia and diverse parts of Africa. The olive tree has a history nearly paying homage to that of western civilization, whose increase has been one of the achievements of the primary guy. At a site in Spain, carbon-relationship has proven the olive seed discovered there whilst it changed into 8,000 years old. Funding of O. Europaea may additionally have originated independently in Crete and Syria. Archaeological evidence shows that olive bushes have been cultivated in Crete as early as 2,500 B.C. From Crete and Syria, olive groves unfold for the duration of Greece, Italy, and components of the Mediterranean basin. NPK fertilizer considering being essential element for plant growth and development. The $16 \mathrm{~g} \mathrm{NPK}$ and $32 \mathrm{~g} \mathrm{~N}$ significantly gave the highest shoot and root dry weight, this probably due to nitrogen concentration which increased dry matter accumulation in roots and decreased shoot $\backslash$ root ratio. As for nonconventional biological resources suitable for soil amendments, biodiversity enhanc- 
es soil characteristics and plant growth (Obreza et al., 1989). Farmyard manure it is complicated substances based on the composition of living things. Agriculture organic matter is known for improving nutrient uptake, drought tolerance, seed germination and overall plant performance (Chen and Avaid, 1990; Sanchez-Andreu et al., 1994). (Fernández-Escobar et al., 1999) mentioned that, under field conditions, foliar application of leonardite extracts (humic substances extracted) stimulated shoot growth and promoted the accumulation of $\mathrm{K}, \mathrm{B}, \mathrm{Mg}, \mathrm{Ca}$ and $\mathrm{Fe}$ in leaves. However, when leaf $\mathrm{N}$ and leaf $\mathrm{K}$ values were below the threshold limit for the sufficiency range, foliar application of humic substances was ineffective to promote accumulation of these nutrients in leaves (Abdel Fatah et al., 2008).

\section{Materials and Methods}

This study was conducted in an open field area at the Balochistan Agricultural Research \& Development Centre, Quetta. Selected one year old Olive tree sapling for research trial. The study with three replications and Randomize Completely Randomized Design (RCBD). Organic fertilizers and mineral fertilizer treatments, initially for one week saplings in all plants were applied fertilizers, later they were grow upped as per following planned fertilizer treatments, $\mathrm{T} 1=($ control $), \mathrm{T} 2=\mathrm{N} 50 \mathrm{~g} / \mathrm{plant}, \mathrm{T} 3=\mathrm{P} 25 \mathrm{~g} / \mathrm{plant}$, $\mathrm{T} 4=$ Potassium $25 \mathrm{~g} / \mathrm{plant}, \mathrm{T} 5=$ NPK 50:25:25/plant, T6 = Biochar 2:2 and T7 = FYM 2:2.

\section{Soil sampling and analyses}

Soil $\mathrm{pH}$ (alkalinity and acidity) and electrical conductivity (EC) soluble ions have been determined in a 1:2 soil-water extract using $\mathrm{pH}$ and $\mathrm{EC}$ meter, respectively. Soil texture turned into determined through hydrometer technique (Bouyoucos, 1936). Soil organic matter by using Walkley-black technique and corrected to nitrate percentage through Vant hoof's issue zero.000.5 (Jackson, 1962). Lime analysis with the aid of acid neutralization technique (Jackson, 1962). Available $\mathrm{P}$ was determined by the Olsen $\mathrm{NaHCO}_{3}$ extraction (Olsen et al., 1954). followed by color development using ascorbic acid method as described by (Murphy and Riley, 1962). Exchangeable $\mathrm{K}$ was determined by extraction with $1 \mathrm{~N} \mathrm{NH}_{4} \mathrm{OAC}$ $\left(\mathrm{CH}_{3} \mathrm{COONH}_{4}\right)$ followed by subjecting the extract on an emission flame photometer as described by (Knudsen et al., 1982).
Plant data generated/recorded

The plant data on growth and development traits were recorded for two times during the study first after three and second after six months of planting viz: height of plant in $\mathrm{cm}$ per plant, leaves per plant, branches per plant and girth of stem in $\mathrm{cm}$ per plant.

\section{Statistical analysis}

The data regarding height of plant in $\mathrm{cm}$, girth of stem in $\mathrm{cm}$, branches consistent with plant and leaves consistent with plant were recorded after three and six months of stressing and subjected to statistical analysis using appropriate procedures and MINITAB software.

\section{Results and discussion}

The data related to the physicochemical analysis of soil results shown in Table 1 . The results given that the soil was fertile sand with sand on the slope, it looked natural with lime contents of $2.2 \%$, low in organic matter and nitrite content $(0.20 \%, 0.001 \%)$, potassium and phosphate were low in range (48 ppm, $2 \mathrm{ppm}$ ). Salt-free with $\mathrm{EC}$ of $1.2 \mathrm{dS} \mathrm{m}^{-1}$, normal in reaction with $\mathrm{pH}$ of 7.7 and had no salinity and sodicity problem. There was $100 \%$ survival of the olive plants under all organic and inorganic mineral fertilizer treatments.

\section{Table 1: Soil fertility status from experimental trial.}

\begin{tabular}{|c|c|c|c|c|c|}
\hline \multirow{2}{*}{$\begin{array}{l}\text { S. No } \\
1\end{array}$} & \multirow{2}{*}{$\begin{array}{l}\text { Parameters } \\
\text { pH (Acid-Alkaline) }\end{array}$} & \multirow{2}{*}{$\begin{array}{l}\text { Results } \\
7.7\end{array}$} & \multicolumn{3}{|c|}{ Permissible Limits } \\
\hline & & & $<7.5$ & $7.5-8.5$ & $>8.5$ \\
\hline 2 & $\mathrm{EC}\left(\mathrm{dS} \mathrm{m}^{-1}\right)$ & 1.23 & $<4.0$ & 4.0 & $>4.0$ \\
\hline 3 & Organic Matter (\%) & 0.20 & & & \\
\hline 4 & Nitrite (\%) & 0.001 & $<0.86$ & 1.29 & $>1.29$ \\
\hline 5 & $\mathrm{P}$ ppm & 2 & $<4$ & $4-7$ & $>7$ \\
\hline 6 & $\mathrm{~K}$ ppm & 48 & $<60$ & $60-120$ & $>120$ \\
\hline 7 & $\mathrm{CaCO}_{3}(\%)$ & 2.2 & $<3$ & 25 & $25>$ \\
\hline \multirow{4}{*}{8} & Textural class & \multicolumn{4}{|c|}{ Sandy silty loam } \\
\hline & Sand (\%) & \multicolumn{4}{|c|}{41.2} \\
\hline & Silt (\%) & \multicolumn{4}{|l|}{51.1} \\
\hline & Clay (\%) & \multicolumn{4}{|l|}{7.7} \\
\hline
\end{tabular}

The results related to response of organic with mineral fertilizer application on olive saplings traits, i.e., height of plant $\mathrm{cm}$, leaves per plant, branches per plant and stem girth $\mathrm{cm}$ of olive saplings for two times i.e. after three and six months of planting are presented in the Figure 1,2, 3 and 4. It is evident from that the organic and inorganic mineral fertilizer result signifi- 
cantly $(\mathrm{P}<0.05)$ increased the height per plant, leaves per plant, branches per plant and stem girth $\mathrm{cm}$ of olive saplings. Compared than control (Without fertilizer).

\section{Plant height perplant}

In various fertilizer treatments result showed in (Figure 1), comparison of treatments, the results indicated significant difference was observed in the plant height. Maximum $(6.58 \mathrm{~cm})$ plant height was observed in treatment-5 (NPK 50:25:25) followed by treatment-2 (N 50g), treatment-3 (P 25g), treatment-7 (FYM 2:2), treatment-6 (Biochar 2:2), T-4 (K $25 \mathrm{~g})$ which produced $(5.25 \mathrm{~cm}, 5.14 \mathrm{~cm}, 5.11 \mathrm{~cm}$, $5.01 \mathrm{~cm}$ and $4.45 \mathrm{~cm}$ ) plant height whereas minimum $(4.22 \mathrm{~cm})$ plant height was recorded in treatment-1 Control at first stage (after three months).

While in second stage (after six months) was collected data the maximum $(7.31 \mathrm{~cm})$ plant height was observed in treatment-5 (NPK 50:25:25) followed by treatment-2 (N 50g), treatment-7 (FYM 2:2), treatment-3 (P 25g), treatment-6 (Biochar 2:2), T-4 (K $25 \mathrm{~g})$ which produced $(5.77 \mathrm{~cm}, 5.65 \mathrm{~cm}, 5.62 \mathrm{~cm}$, $5.51 \mathrm{~cm}$ and $4.89 \mathrm{~cm}$ ) plant height whereas minimum $(4.54 \mathrm{~cm})$ plant height was recorded in treatment-1 Control respectively. Plant height is a feature of genetic as well as environmental situations. Nitrogen and potash boom vegetative increase of vegetation (Khan et al., 2006). The outcomes are agreement with the findings of (Davis et al., 2003) who mentioned comparable effects and growth in plant peak. (Sheo, 1999) studied the sapling of Karun Jamir (C. aurantium) and Cleopatra mandarin (C. reshni) was significantly augmented through urea and FYM unaccompanied or with mixture.

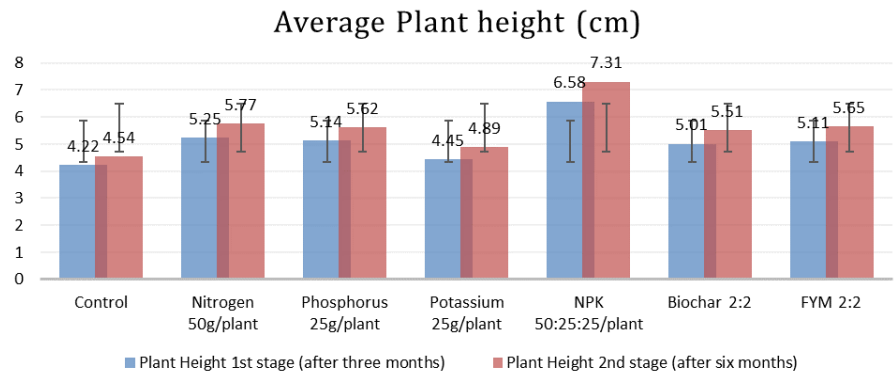

Figure 1: Average height of plant $\mathrm{cm}$.

\section{Leaves per plant}

Results indicated in (Figure 2) the significantly interaction between organic and inorganic mineral fertilizer treatments, the most increase number of leaves per plant observed in treatment-5 (NPK 50:25:25)
(203) number of leaves were observed followed by treatment-2 (N 50g), treatment-3 (P 25g), treatment-7 (FYM 2:2), treatment-6 (Biochar 2:2), T-4 (K 25g) which produced $(125,122,115,107$ and 97) number of leaves whereas minimum (82) number of leaves were recorded in treatment- 1 Control at first stage (after three months).

While in second stage (after six months) was collected data the maximum (276) number of leaves were observed in treatment -5 (NPK 50:25:25) followed by treatment-2 (N 50g), treatment-7 (FYM 2:2), treatment-3 (P 25g), treatment-6 (Biochar 2:2), T-4 (K $25 \mathrm{~g})$ which produced (202, 175, 166, 153 and 147) number of leaves whereas minimum (142) number of leaves were recorded in treatment-1 Control respectively. Furthermore, (Xiloyannis et al., 2000), reported that the growth parameters which have not impact most of mineral fertilizer treatments may be attributed to lack nutritional value of young olive seedlings.

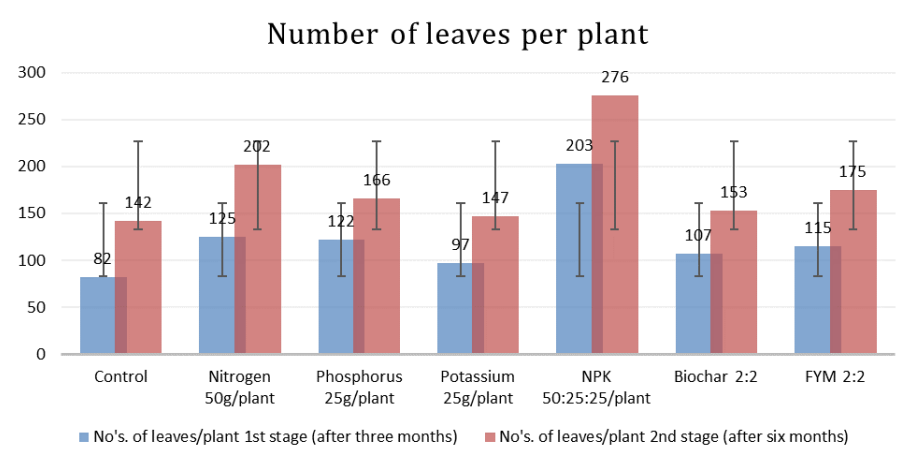

Figure 2: Average number of leaves per plant.

\section{Number of branches per plant}

The results showed in (Figure 3 ) that the application of organic and inorganic mineral fertilizer variable response. The results indicated significant difference was observed in the branches per plant. Highest (8) branches were observed in treatment-7 (FYM 2:2) followed by treatment-3 (P 25g), treatment-5 (NPK 50:25:25) treatment-2 (N 50g), treatment-4 (K 25g), treatment-6 (Biochar 2:2) which produced $(7,7,7$, 6 and 5) branches whereas lowest (4) branches were recorded in treatment-1 Control at first stage (after three months).

While in second stage (after six months) was collected data the maximum (11) number of branches were observed in treatment-5 (NPK 50:25:25) followed by treatment-2 (N 50g), treatment-7 (FYM 2:2), treatment-3 (P 25g), treatment-6 (Biochar 2:2), T-4 (K 25) which produced $(10,10,9,7$ and 9$)$ branch- 
es whereas least (6) branches were recorded in treatment-1 Control respectively. Also, (Yousef et al. 2011) specified that dose of (Humic acid + amino acids + macro elements+ trace elements) found highly most active one than with the additional dose subsequently treated Chemlali olive seedlings with this treatment gave the superlative consequences regarding leaf figures comparing with the control.

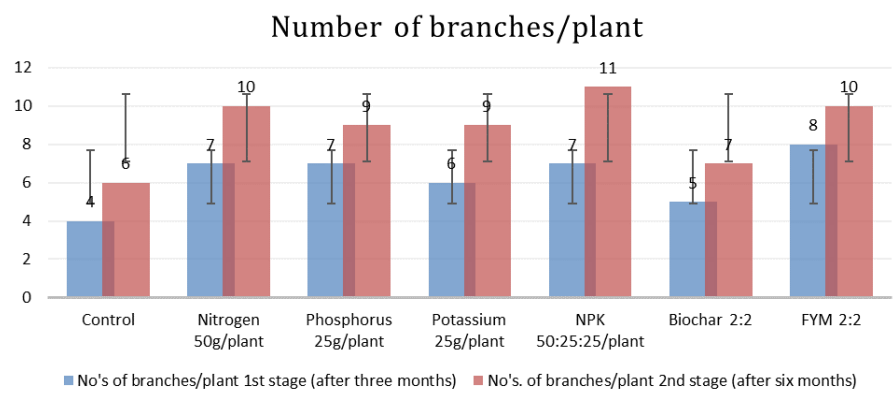

Figure 3: Average number of branches per plant.

Stem diameter per plant ${ }^{-1}$

Stem diameter showed in (Figure 4) varied according to the source of applied organic and inorganic mineral fertilizer. In this respect, stem diameter responded significantly to the increased $(1.5 \mathrm{~cm})$ in treatment-7 (FYM 2:2) followed by treatment-5 (NPK 50:25:25), treatment-3 (P 25g), treatment-2 (N 50g), treatment-4 (K 25g), treatment-6 (Biochar 2:2) which produced $(1.4,1.3,1.3,1.3$ and $1.2 \mathrm{~cm})$ stem diameter whereas minimum (1.2) stem diameter was recorded in treatment-1 Control at first stage (after three months).

While in second stage (after six months) was collected data the maximum $(1.8 \mathrm{~cm})$ stem diameter was observed in treatment-5 (NPK 50:25:25) followed by treatment-7 (FYM 2:2), treatment-2 (N 50g), treatment-3 (P 25g), treatment-6 (Biochar 2:2) and treatment $-4(\mathrm{~K} 25 \mathrm{~g})$ which produced $(1.6 \mathrm{~cm}, 1.5 \mathrm{~cm}$, $1.5 \mathrm{~cm}, 1.4 \mathrm{~cm}$ and $1.4 \mathrm{~cm})$ stem diameter whereas minimum $(1.3 \mathrm{~cm})$ number of $\mathrm{b}$ stem diameter was recorded in treatment-1 Control respectively. (Bonomelli et al. 2010) stated that "during the first growing season, cherry plants on dwarfing Gisela 6 rootstock have low $\mathrm{N}$ demand and low $\mathrm{N}$ uptake efficiency". In regards to inorganic and organic fertilizer application with different forms of nitrogen, applying on olive seedlings cv. Picual gave better results for percentage of height increment, leaves number and root number (About applying organic and organic fertilizers with different types of nitrogen, including olive seedlings cv. Picual has provided better results with a percent- age increase in height, leaving the number and number of roots). For the meantime, applying calcium nitrate found very impressive treatment compared with the others, concerning stem diameter, leaf dry weight and root length. These results partially agreed with (Sheo, 1999) who reported growth of saplings of Karun Jamir (C. aurantium) and Cleopatra mandarin (C. reshni) were significantly highly through applying mineral fertilizer and FYM or with combination. Ameliorative response of $\mathrm{Ca}\left(\mathrm{NO}_{3}\right)_{2}$ on growth of plant were studied by (Al-Harbi 1995), (Türkmen et al., 2002; 2004) and (Belind et al., 1997) since, calcium controls plant growth, ion exchange properties and enzyme activity.

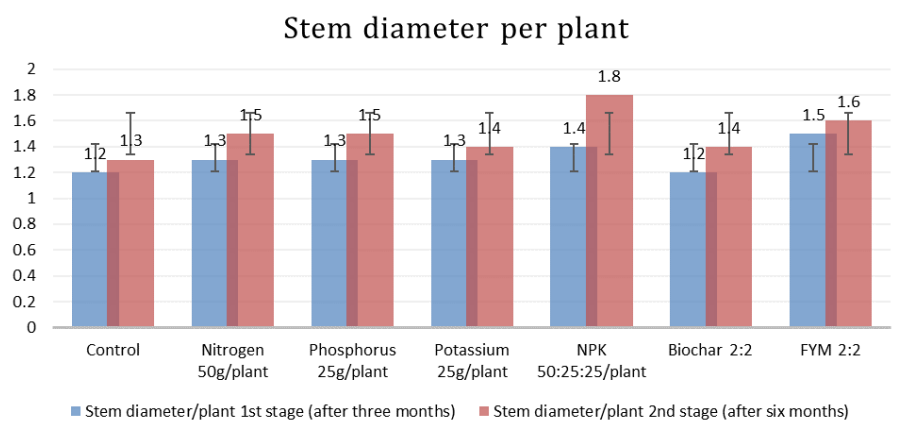

Figure 4: Average stem diameter/girth per plant.

\section{Conclusion and Recommendations}

Balance application of fertilizer can play important role and be very profitable in deficient case of nutrient elements especially for one year old sapling of olive plants. These elements will be rapidly taken up by the trees. Moreover, this technique could be enhancing the fertility of soil.

\section{Acknowledgement}

Author is highly grateful and acknowledge the contributions of whole team of researcher for support and kind guidance. I also express my sincere thanks to Nadeem Sadiq for their technical supports and guidance during the whole study program.

\section{Novelty Statement}

The experiment was laid out at BARDC, Quetta and observed from various of parameters which is growth and developments of olive saplings and soil nutrient status improved through mineral fertilizer when applied in soil during the two periods (three months), besides treatment 5 (NPK 50:25:25) was the superior in this concern. 
Author's Contribution

Muhammad Iqbal Jakhro: conducted field research, set the paper and supervised the research study.

Nadeem Sadiq, Javed Ahmed Abro, Amanullah and

Fateh Muhammad: Provided technical inputs.

Maqbool Ahmed, Ishtiaq Ahmed Shah and Qasid

Hussain: Helped in revised manuscript and gave final shape for publication.

\section{Conflict of interest}

The authors have declared no conflict of interest.

\section{References}

Abdel Fatah, H. Gehan, Boshra, A. E1 Sayed and S.M. Shahin., 2008. The role of humic acid in reducing the harmful effect of irrigation with saline water on tifway turf. J. Biol. Chem. Envion. Sci., 3(1): 75-89.

Al-Harbi and A.R. 1995. Growth and nutrient composition of tomato and cucumber as affected by sodium chloride salinity and supplemental calcium.J. Plant Nutr., 1(8): 1403-1416. https:// doi.org/10.1080/01904169509364990

Belind, J.M., J.A. Menge, C. Amrhein and B. Faber. 1997. The effects of calcium on avocado growth and root health. California Avocado Society, yearbook, 8(1): 69-78.

Bonomelli, C., H. Gilabert and M. Ayala., 2010. Nitrogen uptake, growth and biomass accumulation in the first growing season of cherry trees on Gisela 6. Acta Hort., 86(8): 177-184. https://doi.org/10.17660/ ActaHortic.2010.868.20

Bouyoucos, G.H. 1962. A recalibration of the hydrometer method for making mechanical analysis of soils. Agron. J., 43: 434-438. https:// doi.org/10.2134/agronj1951.00021962004300 090005x

Chen, Y. and T. Aviad. 1990. Effect of humic substances on plant growth.pp:161-186.https:// doi.org/10.2136/1990.humicsubstances.c7

Davis,J.M., D.C. Sanders, P.V. Nelson, L. Lengnick and W.J. Sperry. 2003. Boron improves growth, yield, quality, and nutrients contents of tomato. J. Am. Soc. Hortic. Sci., 128(3): 441-446. https://doi.org/10.21273/JASHS.128.3.0441

Fernández-Escobar, R., M. Benlloch, D. Barranco, A. Dueñas and J.A. Gutérrez Gañán. 1999. Response of olive trees to foliar application of humic substances extracted from leonardite. Sci. Hortic., 66(3-4): 191-200. https://doi. org/10.1016/S0304-4238(96)00914-4

Jackson, M.L. 1962. Soil Chemical Analysis. An Advanced Course. University of Wisconsin Madison, Wise. Pages: $47-88$.

Jackson, M.L. 1969. Soil Chemical Analysis. Constable Co. Ltd., London.

Khan, M.Z., S. Muhammadi, M.A. Naeemi, E. Akhtar and M. Khalid. 2006. Response of some wheat (Triticum aestivum L.) Varieties to foliar application of $\mathrm{N} \& \mathrm{~K}$ under rain-fed conditions. Pak. J. Bot., 38(4): 1027-1034.

Knudsen, D., G.A. Peterson and P.F. Pratt. 1982. Lithium, sodium and potassium In Methods of Soil Analysis, Part 2: Chemical and Microbiological Properties. Page AL (ed.). Am. Soc. Agron., Madison, WI, USA. pp. 225-245. https://doi.org/10.2134/agronmonogr9.2.2ed. c13

Murphy, J., and J.P. Riley. 1962. A modified single solution Brady, N.C., Weil, R.R., 2008. The Nature and Properties of Soils. $14^{\text {th }}$ Edition. Pearson Prentice-Hall Inc., Upper Saddle River, New Jersey, USA. pp. 978.

Obreza, T.A. and R.H. Biggs. 1989. Humate materials: Their effects and use as soil amendments. Citrus Indus, pp: 10.

Olsen, S.R., C.V. Cole. F.S. Watanabe and L.A Dean.1954. Estimation of available phosphorus in soil by extraction with sodium bicarbonate. U.S. Dept. Agric. Circ. 939, Washington D.C.

Sanchez-Andreu, J., J. Jorda and M. Juarez., 1994. Humic substances: Incidence on crop fertility. Acta Hortic., 35(7): 303-316. https://doi. org/10.17660/ActaHortic.1994.357.29

Sheo, G.S.I.P. 1999. Effect of foliar application of urea, GA and $\mathrm{ZnSO}$ on seedling growth of two 34 citrus species. J. Appl. Hortic., 1(1): 51-53.

Türkmen, O., A. Dursun, M. Turan and C. Erdinc., 2004. Calcium and humic acid affect seed germination, growth and nutrient content of tomato (Lycopersicon esculentum L.) seedlings under saline soil conditions. Acta Hortic., Scandinavica B., 5(4): 168-174. https://doi. org/10.1080/09064710310022014

Türkmen, O., S. Sensoy, I. Erdal and T. Kabay. 2002. Effects of calcium on the emergence and seedling growth of tomatoes grown in salty grown media conditions. J. Agric. Sci., 12: 5-53.

Xiloyannis, C., G. Celano, A.M. Palese, B. 
Dichio and V. Nuzzo. 2000. Mineral nutrient uptake from the soil in irrigated olive trees, cultivar Coratina, over six years after planting. Acta Hortic., 58(6): 453-456. https://doi. org/10.17660/ActaHortic.2002.586.93

Yousef, A.R.M., H.S. Emam and M.M.S. Saleh.
2011. Olive seedlings growth as affected by humic and amino acids, macro and trace elements applications. Agric. Biol. J.N. Am., 2(7): 1101-1107. https://doi.org/10.5251/ abjna.2011.2.7.1101.1107 